\title{
Transfusion Medicine in Slovenia - Current Status and Future Challenges
}

\author{
Primož Rožman Dragoslav Domanović \\ Blood Transfusion Centre of Slovenia, Ljubljana, Slovenia
}

\section{Key Words}

Slovenia - National blood supply - Transfusion medicine (definitions, status, future development)

\section{Summary}

A short history of the blood transfusion activities in Slovenia is given, starting with the hommage to Dr. Janez Plečnik, a contributor to the famous experiment of the ABO blood groups discovery by Landsteiner in 1900. The organized blood transfusion services of Slovenia that celebrate the 60th anniversary in 2006 have been traditionally based on a system of unpaid voluntary blood donations which resulted, supported by the Red Cross activities, in satisfactory blood supply outcomes. Due to the increased quality and safety demands for blood products, the major changes and reorganization of the blood transfusion service in Slovenia started in 1990s. In this review, the current situation of blood transfusion services as well as of transfusion medicine in Slovenia is described. Details are given regarding the national legislation, public perception, guidelines, quality systems, accreditation, risk management, cost containment and control, hemovigilance and contingency plans, followed by specific information dealing with the national strategies for the management of immunological risk and for prevention of transmission of diseases by blood transfusion. Finally, the future development of the blood transfusion services of Slovenia is discussed, taking into account the circumstances that point into the direction of further centralization of processing, quality management and national data bases of blood donors and patients.

\section{Schlüsselwörter}

Slowenien · Nationale Blutversorgung · Transfusionsmedizin (Definitionen, Status, zukünftige Entwicklungen)

\section{Zusammenfassung}

Der vorliegende Artikel gibt einen kurzen Abriss der Transfusionsmedizin in Slowenien. Er beginnt mit einer Hommage an Dr. Janez Plečnik, der an dem berühmten Experiment von Landsteiner im Jahr 1900 beteiligt war, das zur Entdeckung der Blutgruppen führte. Die organisierten slowenischen Bluttransfusionsdienste, die im Jahr 2006 ihr 60-jähriges Bestehen feiern, stützen sich traditionell auf ein System unbezahlter Blutspenden, das zusammen mit den Aktivitäten des Roten Kreuzes zu einer zufriedenstellenden Blutversorgung führt. Aufgrund erhöhter Qualitäts- und Sicherheitsanforderungen für Blutprodukte begann in Slowenien in den 1990ern eine weitreichende Umgestaltung und Neuorganisation der Blutversorgunsdienste. In der vorliegenden Übersicht wird die aktuelle Situation der Blutversorgungsdienste und der Bluttransfusion beschrieben. Einzelheiten zur nationalen Gesetzgebung, öffentlichen Wahrnehmung, Richtlinien, Qualitätssicherungssystemen, Akkreditation, Risikomanagement, Kosteneingrenzung und -kontrolle, Hämovigilanz und Notfällen werden dargestellt. Spezielle Informationen zu nationalen Strategien zum immunologischen Risikomanagement und zur Vermeidung der Krankheitsübertragung per Bluttransfusion folgen. Abschließend wird die künftige Entwicklung der slowenischen Bluttransfusionsdienste unter besonderer Berücksichtigung der zunehmenden Zentralisierung der Herstellung und des Qualitätsmanagements sowie der wachsenden Bedeutung von nationalen Spender- und Empfängerdatenbanken diskutiert. 
Table 1. Slovenia - some geographical and demographical data (source: The World Factbook. www.cia.gov/cia/publications/factbook/geos/si.html)

Location

Area

Land boundaries

Coastline

Geography - note

Population

Median age

Birth/death rate

Net migration rate

Sex ratio

Infant mortality rate

Life expectancy at birth

Total fertility rate

HIV/AIDS

Ethnic groups Slovene

Religions:
Central Europe, eastern Alps bordering the Adriatic Sea, between Austria and Croatia

20,273 $\mathrm{km}^{2}$ (compared to Luxembourg 2,586; Israel 20,770 $\mathrm{km}^{2}$ )

1,334 km (Austria 330 km, Croatia 670 km, Italy 232 km, Hungary 102 km)

$46.6 \mathrm{~km}$

This eastern Alpine country controls some of Europe's major transit routes

2,010,347 (July 2006 est.)

40.6 years (male: 39 years; female: 42.2 years) (2006 est.)

8.98 births vs. 10.31 deaths $/ 1,000$ population (2006 est.)

0.88 migrant(s)/1,000 population (2006 est.)

0.95 male(s)/female (2006 est.)

4.4 deaths/1,000 live births (2006 est.)

76.33 years (male: 72.63 years; female: 80.29 years) (2006 est.)

1.25 children born/woman (2006 est.)

Adult prevalence rate: less than 0.1\% ; people living with HIV/AIDS: 280; deaths: less than 100 (2003 est.)

$83.1 \%$, Serb $2 \%$, Croat $1.8 \%$, Bosniak $1.1 \%$, other or unspecified $12 \%$ (2002 census)

Catholic $57.8 \%$, Orthodox 2.3\%, other Christian $0.9 \%$, Muslim 2.4\%, unaffiliated 3.5\%, other or non or unspecified 33.1 (2002 census)

The Slovenian language, with Hungarian and Italian in ethnically mixed areas.

$99.7 \%$

USD 18,300 (2003)

Literacy

GDP per capita

Number of doctors: 21.8; Number of dentists: 5.9; Number of nurses: 71.5; Number of hospital beds: 51.6

\section{Introduction}

The Republic of Slovenia is a country that established its independence in 1991 (for demographic data see table 1). In the past, Slovenia was part of the Austro-Hungarian Empire. After its breakup in 1918, the Slovenes joined the Serbs and Croats in forming a new multinational state named Yugoslavia. After World War II, Slovenia became a republic of the renewed Yugoslavia from which it seceded in 1991. Soon it became a member state of the United Nations and acceded to the European Union (EU) in 2004. Slovenia is currently strengthening its international position as a democratic, stable and successful European state and is prepairing to introduce the Euro currency on 1 January 2007 and to hold the Presidency of the European Union in 2008 [1-3].

\section{Social Security and the Health Care System in Slovenia}

The level of health care in Slovenia is comparable with the level of health care in the advanced countries of Europe. Under the provisions of the country's constitution, the state is bound to organize compulsory health, pension, disability and other social insurances. Health care is a public service provided through the public health service network, which includes public and private institutions on the basis of concessions. The health insurance is divided into compulsory health insurance and voluntary health insurance for additional coverage. Owing to an increasing proportion of elderly people (demographic changes in Slovenia are among the least favorable) and to a growing number of patients with chronic illness, the costs of health care are rising steeply. The competent body for planning and implementing health care is the Ministry of Health [4].

Transfusion Medicine in Slovenia

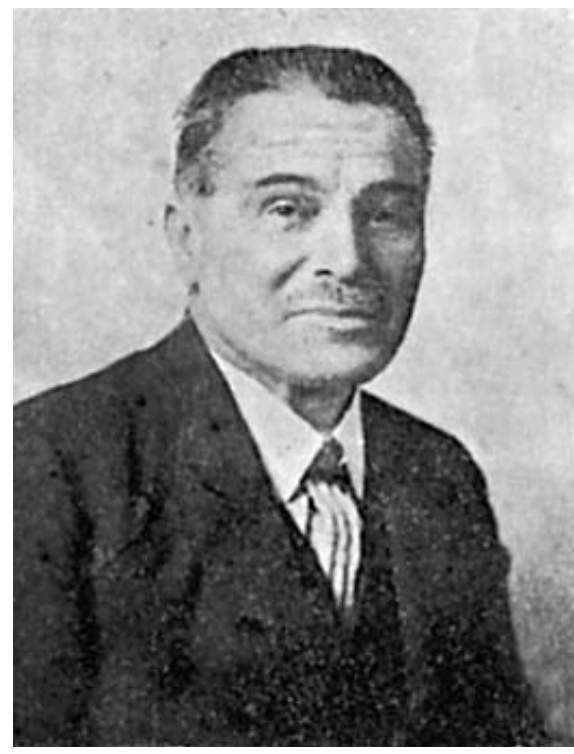

2. Dr. Janez Plečnik, (1875-1940)

\section{Blood Transfusion Service}

The blood transfusion services in Slovenia celebrate the 60th anniversary in 2006, but the beginnings of blood transfusion originate from earlier times. One of the founders of transfusion medicine in Slovenia was the extraordinary physician Dr. Janez Plečnik (1875-1940) (Fig. 1) who, with some other young doctors, assisted to Dr. Karl Landsteiner at the Vienna Institute of Anatomy and Pathology in 1900. In the famous experiment of Dr. Landsteiner, erythrocytes from Dr. Sturli, Dr. Plečnik, Dr. Störk, Dr. Erdheim, the technician Zarič and Dr. Landsteiner were mixed with their serums in a jigsaw puzzle manner, which finally led to the discovery of the ABO 
Fig. 2. Current organization of blood transfusion services in Slovenia, with the number of donations in 2004 [10].

At 2 major blood centers - the National BTC Ljubljana and the Transfusion Department of the Teaching Hospital Maribor - all transfusion-related activities are performed. At 4 hospital-associated blood banks (Celje, Slovenj Gradec, Novo mesto and Izola) some processing but no testing is still performed; whereas at 5 hospital-associated blood banks (Jesenice, Nova Gorica, Trbovlje, Ptuj and Murska Sobota) only collection, issuing and crossmatching procedures are performed.

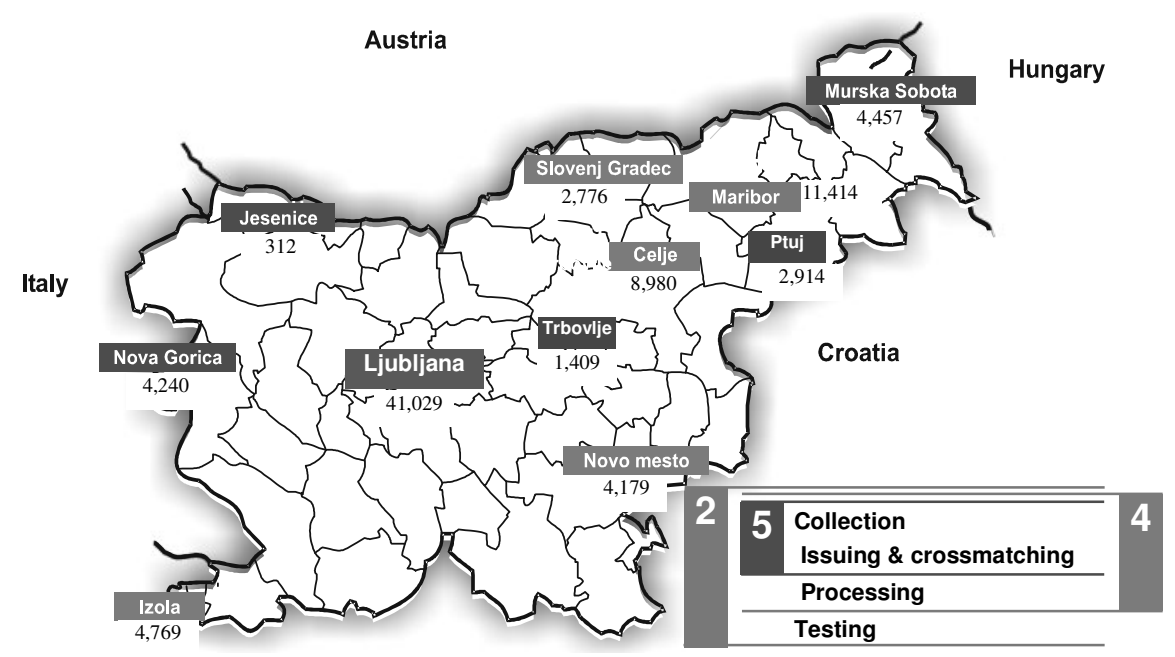

blood group system and laid the foundation for the further development of transfusion medicine [5]. Dr. Plečnik, the first man with determined blood group B, later co-founded the Medical Faculty in Ljubljana, where he became a professor of anatomy and in 1922/23 the Dean. He has remained famous for his activities regarding Slovenian medical terminology that is still in use today.

Although the first blood transfusion in Slovenia had already been reported in 1926 [6] and the direct transfusions became more frequent in the period 1938-1945, the development of an organized blood transfusion service actually commenced after World War II. Between 1945 and 1970, the blood supply system was gradually established followed by the technical and professional progress of blood transfusion facilities between 1970 and 1991. After 1991, the quality system was gradually introduced by complying to the regulations of the EU, Council of Europe and World Health Organization (WHO).

The blood transfusion service of Slovenia has always been based on an unpaid system of blood donations and has been organized as a public service that cannot be performed in any private way. Therefore, all transfusion-related establishments are non-private and non-profit [7]. From the very beginning, recruitment of blood donors and the organization of the donor sessions has been delegated to the Slovenian Red Cross. Although unpaid since 1953, the blood donors still have the right of one day-off from the work, which is legally covered by the Employment Relationship Act, article 169. The costs of absence are paid by the employer to the debit of health insurance [8].

Until 2000, the blood transfusion service consisted of a national Blood Transfusion Center (BTC) in Ljubljana and 10 hospital-associated blood banks. All of them have pursued the complete range of blood transfusion-related activities, including collection, testing, processing, etc. The reorganization of the blood transfusion service had already been postulated in 1997 by a group of experts at the BTC Ljubljana (the present au- thors included), but unfortunately it was not realized. The reorganization actually started in 2001 with the project named 'Establishing Quality Assurance in the Centres for Blood Supply in Slovenia' that has been initiated in the context of the EU accession process with help of the Government of Netherlands [9]. This project that had come well before the EU Directive 2002/98/EC and had envisaged a uniform, centralized system with a uniform quality management, has not been realized due to the circumstances that are beyond the scope of this review. Despite this, the reorganization of the blood transfusion service continued driven by the European legislation, especially after the EU Directive 2002/98/EC. Currently, blood is collected by 11 organizations -2 blood transfusion establishments and 9 hospital-associated blood banks. Serological testing is performed by the national BTC Ljubljana and by the Blood Transfusion Department, Teaching Hospital Maribor (approximately 64 and 36\% of all donations, respectively). The nucleic acid testing (NAT) is performed centrally at the BTC Ljubljana. Four of the remaining 9 hospital-associated blood banks still perform the processing, whereas the other five only perform the collection, issuing and crossmatching (fig. 2).

In 2004, 94,935 blood donors were registered, representing $4.75 \%$ of the population. 86,479 blood collections were carried out during 1,070 blood donation sessions. Of these, 323 were organized at the field collection sites. Altogether, 83,694 red blood cell (RBC) units, 33,951 random platelet units, 1,394 platelet apheresis units and 27,991 1 of plasma were processed. Among the whole blood donors, $10 \%$ presented as first-time blood donors [10].

Transfusion services have also developed a range of activities other than blood banking. The BTC Ljubljana has developed various transplantation-related activities since the 1960 s, e.g. immunogenetics and histocompatibility laboratories, resulting in the formation of the Slovenia-transplant organization, which is a member of the Eurotransplant (www.euro- 
transplant.nl) bearing the EFI accreditation in 2000 (www.efiweb.org). The BTC is also involved in collection, processing and storage of hematopoietic stem cells, cellular therapies, and tissue banking. Based on major improvements in the blood transfusion services in the last few years, Slovenia became a member of the European Blood Alliance (EBA) in 2005 (www.eba-web.org).

\section{Legislation, Politics and Public Perception}

The old Supply of Blood Act I from 2000 [11] has recently been harmonized with the EU Directive 2002/98/EC, and the new Supply of Blood Act II is expected to be accepted in 2006. Several additional regulations were issued during 2000-2004, covering the following fields: medical conditions regarding blood donations, documentation on the use of blood and blood products, the statutes of the National Council for Blood Supply (the political body formulating the national policy of blood supply), testing of blood for the transfusion-transmittable infections, storage, transport, handling and disposal of non-used blood and blood products, as well as collection, storage and use of hematopoietic stem cells.

The new Blood Supply Act II brings strict regulations regarding the quality and safety of the blood supply as envisaged by the EU Directive 2002/98/EC. The daughter directives - Directive 2005/62/EC (regarding the standards of quality systems) and the Directive 2005/61/EC (regarding the traceability) - will be covered by amending regulations to the Supply of Blood Act II by the end of 2006. Although the new legislation will not generate full unification of the blood supply system, essential items will be warranted: a common blood transfusion information system, a national competent authority (Blood Department of the Agency for Medicinal Products and Medical Devices at the Ministry of Health), a national system of hemovigilance and compulsory quality systems. As a result, distinct political, regulatory and expert bodies existing at the Ministry of Health will formulate the national blood transfusion policy, accredit the blood establishments and supervise the professional activities.

A national survey from 2004 showed that the public perception of the national blood transfusion service of Slovenia is very positive [12]. This was proven by the absence of any serious shortages in blood supply during 2002-2006.

\section{Standards, Quality and Accreditation}

\section{National Guidelines, Quality Systems and Policies}

National blood transfusion guidelines do not exist in a single issue. They comprise several regulations based on the Supply of Blood Act I. The Council of Europe's 'Guide to the Preparation, Use and Quality Assurance of Blood and Blood Components' [13] has been adopted in 2002 as the national blood transfusion standard. Quality management system according to ISO standard 9001:2000 has been introduced at two blood establishments in Ljubljana and Maribor (in 2004 and 2005, respectively), whereas in the remaining 9 hospital-associated blood banks, these tasks remain to be finished in the near future. The blood transfusion activities have been backed up since 1989 with a national blood transfusion information system, DATEC, that is now outdated. The introduction of the new system Progesa is associated with considerable difficulties and has been in preparation since 2003. Its full implementation is expected in 2007.

\section{Corrective and Preventive Actions, Risk Management}

The corrective and preventive actions are already included in the ISO9001:2000 standard. In the case of the possible transmission of infection by transfusion, the special medical board analyses and reports the results of the analysis and takes appropriate action. The risk management has not been currently covered in a comprehensive way, but is covered by various other procedures within the ISO9001:2000 systems.

\section{Accreditations}

National accreditation will be formed by the new Supply of Blood Act II in 2006. Blood establishments will acquire their permissions, certificates or licenses based on official procedures at the competent authority. Currently, all blood establishments operate based on the official permissions of the Ministry of Health.

\section{Cost Containment and Cost Control (Products)}

There is currently no defined unique cost containment and cost control program for the blood transfusion services. The main control mechanisms therefore remain the governmental regulations and the practical negotiations between the blood transfusion service members (suppliers) and the Health Insurance Institute of Slovenia (representing the consumers). In the nearest future prices of blood components and plasma products are expected to be controlled by the Ministry of Health under the Supply of Blood Act II. However, the transparency of the costs and financing remains elusive until the complete unification of the blood transfusion services is reached.

\section{Hemovigilance}

The Supply of Blood Act I from 2000 established the mandatory reporting of all adverse transfusion reactions. A complete hemovigilance system was set up in 2002. It consists of the reports about adverse reactions and events during any time between the collection and the distribution of blood, and of the reports about adverse reactions that arise during and after blood transfusion. The 'Notification of Adverse Reaction of Blood Transfusion' form is filled in by the physician at the hospital, and the 'Report on Adverse Effects of Blood Transfusion' form is filled in by the transfusion medicine specialist at the blood transfusion site. The hemovigilance activities are coordinated and operated by the BTC, while the National Hemovigilance Center is located within the Agency for Medici- 
Table 2. Adverse reactions of blood transfusion in Slovenia 2004, with respect to the causative blood product

\begin{tabular}{|c|c|c|c|c|}
\hline \multirow[t]{2}{*}{ Type of AR } & \multicolumn{3}{|c|}{ Blood components } & \multirow[t]{2}{*}{ Sum } \\
\hline & $\mathrm{RBCs}$ & $\begin{array}{l}\text { Platelet } \\
\text { concentrates }\end{array}$ & FFP & \\
\hline Hemolysis & 2 & 0 & 0 & 2 \\
\hline GVHD & 0 & 0 & 0 & 0 \\
\hline TRALI/pulmonary edema & $0 / 2$ & 0 & 0 & $0 / 2$ \\
\hline Allergergic/anaphylactic & $33 / 2$ & 3 & $18 / 4$ & 60 \\
\hline FNHR & 62 & 5 & 1 & 68 \\
\hline Bactially/virally contaminated & 0 & 0 & 0 & 0 \\
\hline Other & 9 & 4 & 1 & 14 \\
\hline Sum & 110 & 12 & 24 & 146 \\
\hline Total number of units & 77,630 & 25,680 & 32,988 & 136,298 \\
\hline Number of AR / 1,000 units & 1.42 & 0.47 & 0.73 & 1.07 \\
\hline $1 \mathrm{AR} /$ number of units & $1 / 706$ & $1 / 2,140$ & $1 / 1,374$ & $1 / 933$ \\
\hline Anaphylactic / number of units & $1 / 38,815$ & 0 & $1 / 8,247$ & $1 / 22,716$ \\
\hline
\end{tabular}

$\mathrm{AR}=$ Adverse reaction; FNHR = febrile non-hemolytic reaction; GVHD = graft versus host disease TRALI = transfusionassociated lung injury. nal Products and Medical Devices at the Ministry of Health. Hemovigilance is still finding its way in various hospitals. In our opinion, there is a considerable underreporting of adverse reactions, so additional efforts of the hospital Blood Transfusion Committees that have been obligatory since 2000 are necessary. Some details from the Hemovigilance Report 2004 are given in table 2 .

\section{Contingency Plans}

There is a draft plan for blood supply in catastrophic disaster situations waiting to be accepted by the National Council for Blood Transfusion. The BTC Ljubljana is the coordinating authority for the blood supply in disaster situations and is also responsible for the emergency blood supply planning. The Blood Transfusion Department in Maribor will take over the coordination in the case of a catastrophic event in Ljubljana. In the first $24 \mathrm{~h}$ after a catastrophic event, the needs for RBCs should be covered by the units from the national stock of RBCs. The minimal stock (7-day RBC stock of all ABO blood groups and a 1-day stock of blood group O RBCs) is accepted. In addition, approximately 7,000 bottles of $20 \%$ human albumin are kept stored for the case of emergency and catastrophic disaster.

\section{Specific Topics}

\section{Management and Prevention of Immunological Risks}

To prevent acute immune-mediated hemolytic transfusion reactions, the transfusion process is checked in every phase for errors, and computer-assisted pre-transfusion testing is done. There are written procedures for patient-sample-component identifications. Bedside ABO testing at the time of transfu- sion is still obligatory. Pre-storage leukoreduced, filtered blood components are used for suspect cases. There is no panel of IgA-deficient blood donors. Regularly, ABO and $\mathrm{RhD}$ compatible RBCs are transfused. There is no common policy regarding the use of CE- positive units although the majority of units are transfused CE compatible. Since autumn 2006, only K (Kell) compatible units will be transfused to all patients. Transfusion-associated graft versus host disease is prevented by irradiation of blood components according to the published international guidelines [14]. For the prevention of transfusion-related lung injury, a policy of not using plasma from female donors has been accepted recently. The common national blood donor database is under construction.

\section{Strategies for the Prevention of the Transmission of Viruses, Bacteria and Parasites}

There is a uniform obligatory questionnaire in which specific questions are addressed to the donor with regard to his/her current health, viral infections, traveling habits, social and sexual life, etc. The eligibility criteria for the donors are implemented in accordance with the technical requirements of Directive 2004/33/EC. Donors have the opportunity of confidential self-exclusion. It is interesting that not a single case of confidential self-exclusion has been reported until now.

For clinical use, fresh frozen plasma (FFP) from quarantine is used at some but not all blood transfusion sites due to the lack of a common national policy in the past. In order to improve this, a centralized viral inactivation of FFP and platelets is under consideration. It has been decided to gradually implement universal leukoreduction in 3 years. At the moment, $20-30 \%$ of blood components are pre-storage filtered. Additional $5 \%$ are filtered after storage. Regular bacteriological 
Table 3. Screening for infectious markers among blood donors (Slovenia 2000-2004)

\begin{tabular}{|c|c|c|c|c|c|}
\hline Marker & Method of testing & Manufacturer & $\begin{array}{l}\text { Frequency of } \\
\text { positive donation* }\end{array}$ & $\begin{array}{l}\text { Prevalence - } \\
\text { first time donors, \% }\end{array}$ & Year of implementation \\
\hline HBsAg & EIA/CLIA & $\begin{array}{l}\text { LJ: Abbott/Prism } \\
\text { MB: Behring/BEP III }\end{array}$ & $\begin{array}{l}0,021 \% \\
(1 / 4,735)\end{array}$ & 0.2 & 1970 \\
\hline Anti-HIV 1/2/0 & EIA/CLIA & $\begin{array}{l}\text { LJ: Abbott/Prism } \\
\text { MB: Behring/BEP III }\end{array}$ & $\begin{array}{l}0,001 \% \\
(1 / 89,286)\end{array}$ & 0.01 & 1986 \\
\hline Anti-HCV & EIA/CLIA & $\begin{array}{l}\text { LJ: Abbott/Prism } \\
\text { MB: Ortho/BEP III }\end{array}$ & $\begin{array}{l}0.01 \% \\
(1 / 11,136)\end{array}$ & 0.14 & 1993 \\
\hline $\begin{array}{l}\text { Anti-Treponema } \\
\text { pallidum }\end{array}$ & EIA & $\begin{array}{l}\text { LJ: Trepanostika Murex } \\
\text { ICE (Summitt processor) } \\
\text { MB: Behring/ } \\
\text { Enzygnost Syphilis }\end{array}$ & $\begin{array}{l}0.01 \% \\
(1 / 9,891)\end{array}$ & 0.1 & $\begin{array}{l}\text { Kolmer, VDRL: } 1960 \\
\text { TPHA: } 1986 \\
\text { EIA: } 2000\end{array}$ \\
\hline HCV RNA & PCR & AmpliScreen (Roche) & $0(\mathrm{NAT}+, \mathrm{Ab}-)$ & 0 & 2000 \\
\hline
\end{tabular}

*Number of tested donations between 2000 and 2004: 445,062.

LJ = BTC Ljubljana; MB = Teaching Hospital Maribor.

screening of platelet units has not yet been implemented and is only performed as regular quality control.

Data regarding infection markers serological and NAT screening is given in table 3. In 2005, there was a documented case of HBV transmission from a donor who was serologically HBsAg-negative. Based on the fact that the respective sample was HBV NAT-positive, obligatory NAT testing on single donations for HIV, HBV and HCV has been introduced in 2006.

\section{Future Challenges}

The teaching of transfusion medicine should be intensified at the graduate and postgraduate levels. Regular symposia for the surgeons, hematology specialists, and other health professionals will be organized in order to reduce unnecessary transfusions as well as to lower the rate of expired blood components, thereby improving the cost efficiency of transfusion practice. The regular blood transfusion courses for certain specialties (surgeons, internal medicine specialists, gynecologists, obstetricians, oncologists, and some others) should be expand- ed and remain compulsory for their curricula. The blood transfusion research will be oriented into the safety issues and cellular therapies.

Blood processing procedures should be centralized into a maximum of two blood establishments (Ljubljana and Maribor) due to the economy of scale and quality reasons [15]. The concept of the unified national BTS has by now been adopted by several transfusion experts and workers in the blood transfusion service as well as by hospital directors and clinicians, indicating the irreversibility of the merging process. For the merging of regional blood transfusion establishments into a well organized National Blood Transfusion Service the key remains in the hands of health authorities.

\section{Conclusion}

It is likely that the reorganization of Slovenian blood transfusion service will continue and that the centralization of processing, quality management and national data bases of blood donors and patients may occur in near future.

\section{References}

1 Government of the Republic of Slovenia, Government Office for European Affairs: Lisbon strategy. 2006.

www.svez.gov.si/index.php?id $\% 20=\% 20973 \% 20$ an d\%20L $\% 20=\% 201$.

2 Republic of Slovenia, Public Relations and Media Office. Government of the Republic of Slovenia Government Office for European Affairs. Presidency.2006.

www.gov.si/vrs/index.php?lng\%20=\%20eng.
3 Republic of Slovenia, Public Relations and Media Office: Slovenia in brief. 2006. www.uvi.si/eng/slovenia/in-brief/.

4 Republic of Slovenia, Public Relations and Media Office: Social security and health care. 2006. www.uvi.si/eng/slovenia/in-brief/health/.

5 Landsteiner K: Ueber Agglutinationserscheinungen normalen menschlichen Blutes. Wien Klin Wochenschr 1901;14:1132-1134.

6 Potočnik M: 50 years of the blood transfusion service in Slovenia 1945-1995. Ljubljana, Blood Transfusion Centre of Slovenia, 1995.
7 Anonymous: Blood Transfusion Centre of Slovenia. 2006. www.ztm.si/php/grid.php/splosno/nagovor.html? Lang $\% 20=\% 20$ en.

8 Employment Relationship Act: www.id.gov.si/index.php?id $\% 20=\% 202592 \% 20$ and $\% 20 L \% 20=\% 201 \% 202006$.

9 Anonymous:Establishing quality assurance in the centres for blood supply in Slovenia Final Report. MATRA PRE-ACCESSION PROJECT MAT0/SL/9/1. 1-22. Amsterdam, Netherlands School of Public and Occupational Health, 2003. 
10 Bricl I, Lampreht N, Potočnik M: Life flows - published at the 60th anniversary of transfusion medicine in Slovenia. Ljubljana, Blood Transfusion Centre of Slovenia, 2006.

11 Anonymous:Supply of Blood Act. Official Gazzete of RS. Uradni list RS 52, 6942. 2000.

12. Šešerko L: Preskrba s krvjo in krvodajalski potencial v Sloveniji. The blood supply and the blood donors potential in Slovenia. Zdrav Vestn 2004; 73(suppl 1):73-76.

13 Guide to the Preparation, Use and Quality Assurance of Blood and Blood Components, 8th ed. Strasbourg, Council of Europe Publishing, 2002.

14 Guide to the Preparation, Use and Quality Assurance of Blood and Blood Components, 11th ed. Strasbourg, Council of Europe Publishing, 2005.

15 Pereira A: Economies of scale in blood banking: a study based on data envelopment analysis. Vox Sang 2006;90:308-315. 